\title{
THE DIFFERENCES IN SELECTED HEALTH-RELATED BEHAVIOUR INDICATORS AMONG WOMEN WITH DIFFERENT EDUCATIONAL ATTAINMENT IN SLOVENIA RAZLIKE V IZBRANIH KAZALNIKIH VEDENJ, POVEZANIH Z ZDRAVJEM, MED RAZLIČNO IZOBRAŽENIMI ŽENSKAMI V SLOVENIJI
}

Mojca Gabrijelčič Blenkuš ${ }^{1}$, Metka Mencin Čeplak², Maja Bajt', Aleš Korošec ${ }^{1}$, Janet Klara Djomba ${ }^{1}$, Jožica Maučec Zakotnik ${ }^{1}$, Cirila Hlastan Ribič ${ }^{1}$, Helena Jeriček Klanšček ${ }^{1}$

Prispelo: 22. 10. 2012 - Sprejeto: 7. 1. 2013

Original scientific article UDC 316.344:614

\begin{abstract}
Background: Numerous studies have found significant gender differences in health-related behaviour, while a lower number analyse these differences within the gender. The aim of the article is to analyse the differences in individual health-related behaviour indicators among women from different educational groups in Slovenia.

Methods: The analysis is based on the CINDI Health Monitor (2008) survey for Slovenia. The nationally representative sample was chosen using probability sampling and the analysis included 4,237 women aged 25 to 74 . The independent variables are: education, in consideration of age, community type, region of residence, the presence of a partner and children and self-perceived social class. The dependent variables are health-related behaviours: nutrition, physical activity, sleeping, stress and care for own health. By comparing averages in health-related behaviour with education and other factors and by classifying participants into homogenous groups, we were able to show differences in health-related behaviour in women with different educational attainment.

Results: Individual health-related behaviour indicators show statistically significant differences between groups of women with different educational attainment; however these are neither very distinct nor unambiguous. Women with a higher educational attainment evaluate the majority of the indicators more favourably than women in other educational groups, but differences can also be found within the group of women with a higher educational attainment. The differences in the health-related behaviour of women with a lower educational attainment are relatively blurred. Conclusion: The relatively small differences in health-related behaviour can be partially explained by existing differences within the group of women with a higher educational attainment and the fact that the group of women with the lowest educational attainment does not have the worst health-related behaviour indicators, which affects the greater equality in health-related behaviour. On the other hand, the well-established universal and targeted family and child care policies, which have been implemented in Slovenia for decades, also affect these results.
\end{abstract}

Key words: health-related behaviour, education, health inequalities, women, nutrition, physical activity, stress, total sleep time, care for own health

Izvirni znanstveni članek UDK 316.344:614

\section{Izvleček}

Uvod: Številne raziskave ugotavljajo pomembne razlike med spoloma $v$ vedenjih, povezanih z zdravjem, manj pa jih analizira razlike znotraj spola. Namen prispevka je analizirati razlike $v$ izbranih kazalnikih vedenj, povezanih $z$ zdravjem, med različnimi izobrazbenimi skupinami žensk v Sloveniji.

Metode: Analiza temelji na raziskavi »Z zdravjem povezan vedenjski slog «, 2008. Nacionalni reprezentativni vzorec ljudi je bil izbran na osnovi verjetnostnega vzorčenja; v analizo je vključenih 4.237 žensk, starih od 25 do 74 let. Neodvisne spremenljivke so: izobrazba, upoštevajoč še starost, tip naselja, regijo prebivanja, prisotnost partnerja in

${ }^{1}$ National Institute of Public Health Slovenia, Trubarjeva 2, 1000 Ljubljana, Slovenia

${ }^{2}$ University of Ljubljana, Faculty of Social Sciences, Kardeljeva ploščad 5, 1000 Ljubljana, Slovenia

Correspondence to: e-mail: helena.jericek@ivz-rs.si 
otrok ter samoocenjeni družbeni sloj. Odvisne spremenljivke so z zdravjem povezana vedenja: prehrana, gibanje, spanje, stres in skrb za zdravje. S primerjavo povprečij v vedenjskem slogu med izobrazbo in drugimi dejavniki ter razvrstitvijo $v$ homogene skupine smo prikazali razlike $v$ vedenjskem slogu med različno izobraženimi ženskami.

Rezultati: Med različnimi izobrazbenimi skupinami žensk so pri posameznih kazalnikih vedenj, povezanih z zdravjem, statistično pomembne razlike,ki pa niso zelo izrazite niti enoznačne. Bolj izobražene ženske večino kazalnikov ocenjujejo ugodneje kot ženske $v$ drugih izobrazbenih skupinah, vendar tudi med bolj izobraženimi ženskami obstajajo razlike. Razlike $v$ vedenjskem slogu pri ženskah z nižjimi stopnjami izobrazbe so sorazmerno zabrisane.

Zaključek: Sorazmerno majhne razlike $v$ vedenjskem slogu je deloma mogoče razložiti z razlikami v skupini visoko izobraženih žensk in dejstvom, da skupina najnižje izobraženih žensk nima najslabših kazalnikov vedenjskega sloga, kar vpliva na večjo enakost v vedenjskem slogu, deloma pa z dobro vzpostavljenimi univerzalnimi in s ciljnimi politikami varstva otrok in družine, ki so bile desetletja v veljavi v Sloveniji.

Ključne besede: vedenjski slog, izobrazba, neenakosti v zdravju, ženske, prehrana, telesna dejavnost, stres, skupni čas spanja, skrb za zdravje

\section{INTRODUCTION}

Health-related behaviour includes various behaviours, such as cigarette smoking, alcohol consumption, the use of illicit drugs, nutritional habits, physical activity, coping with stresses, sleeping habits, social contact, etc. These behaviours can be an important risk factor for obesity, chronic non-communicable diseases and mental disorders or protective factors for good health (1-2).

In recent decades, the number of studies of (public) health that try to explain the connections between numerous macrosocial, demographic and (socio-) psychological factors and health-related behaviours is growing. In order to consider as many relevant factors as possible, the differences/similarities between the different population categories are analysed. Most commonly, these categorisations are made on the basis of gender, age, community type, socioeconomic position, education and occupation (3-4).

Analyses of health-related behaviour are usually limited to one or a smaller number of indicators and only a few analyse several behaviours simultaneously (5-7). Among the demographic factors that are usually analysed, gender and education level stand out. Studies that analyse a greater number of socioeconomic or demographic factors are rare (8). One of the consequences of this research practice is maintaining the impression that gender is a homogenous category. Numerous studies have found significant gender differences in behaviour (9-10), while a lower number analyse these differences within the gender (11). Our study focuses precisely on this aspect. It analyses the differences among women, whereby special attention is paid to education while at the same time pointing out the simultaneous effect of other socioeconomic and demographic factors.
In everyday political and scientific discourses, education, or the level of educational attainment, is seen as a key investment in the future and represents an important factor for the quality of life and a condition for the autonomous and rational management of living conditions (12). Access to education is thus seen as one of the key factors for reducing social inequalities and consequently also health inequalities $(10,13)$ and for the emancipation of marginalised social groups. The demand for women's equal access to education was actually one of the first demands in the history of feminist activism (14). Numerous studies confirm the assumption that there is a connection between health and health-related behaviour on the one hand and education level on the other (15-16) but mostly do not allow us to form causal explanations of this connection (15). The relationship between health and health-related behaviour and education is exceptionally complex: education may affect health and vice versa, while they can also affect each other simultaneously. Furthermore, several different factors can simultaneously affect education and health (15).

Health-related behaviour, health and women's education studies (the latter being relatively small in number both in Slovenia and globally, as the object of a study is usually the general population) indicate that the connections between education, health and health-related behaviour are not unambiguous. On average, women with a higher educational attainment are more exposed to stress, which they usually manage better however than women with a lower educational attainment (17-18). In turn, this probably also affects the lower levels of depression among women with a higher educational attainment (19). On average, women with a higher educational attainment more frequently have healthier eating habits than women with a lower 
educational attainment (9) and are more likely to be sufficiently physically active (20). Risk factors for insufficient physical activity are predominantly poor socioeconomic conditions (21-22), lower income and residence in underprivileged areas (23). On the other hand, life in urban environments facilitates a higher level of physical activity regardless of socioeconomic status (21). Studies show that unhealthy eating in the lower socioeconomic classes is not a consequence of a lack of knowledge or information but above all of the unavailability of healthy food for financial reasons (24). In studying the effects of shift work on women's health, education for example was not established as a protective factor (25), and nor was short sleep duration in the risk of obesity (26). A study among women in Canada (17) has shown that women with a higher educational attainment on average manage stress better than less-educated women but at the same time pointed out that regardless of education, divorced women, non-owners of houses, unemployed women and women with lower income are significantly more exposed to stress. This data points out that in studying health-related behaviour, numerous other factors need to be considered in addition to education.

The aim of this article is to analyse differences in selected health-related behaviour indicators among different educational groups of women in Slovenia, which is the first analysis of its kind in our country. It analyses the differences in self-assessed care for own health, stress exposure and its management, good and bad individual nutritional habits, physical activity habits and total sleep time per day, which are typical health-related behaviour indicators. These behaviours are key health-related behaviours that are usually more permanent and related to the onset of numerous diseases (1, 10, 27-29). As mentioned before, in addition to education, our analysis also considers the differences between educational groups in consideration of individual other demographic and socioeconomic variables: age, community type and geographic region, partnership and motherhood and self-perceived social class. Our main assumption is that there are differences in individual health-related behaviour indicators between different educational groups of women.

\section{METHODS AND SAMPLE}

\subsection{Study description}

The data is taken from the interval cross-sectional epidemiologic CINDI Health Monitor study, which was conducted via postal survey in the spring of 2008. The questionnaire was summarised from the CINDI Health Monitor Survey (30) but adapted to conditions in Slovenia. The study was approved by the National Medical Ethics Committee of the Republic of Slovenia.

\subsection{Sample description}

The target population of the survey consisted of residents of Slovenia aged 25 to 74 . The sampling frame was the Central Population Register. The sample was chosen using probability sampling - i.e. simple random sampling and stratified by health regions. 15,963 persons were invited to participate in the survey. The sample was representative with respect to gender, age and health regions (31).

The analysis covers only data on women, with 4,237 or $53.1 \%$ of all the women invited to the survey being appropriate. $21 \%$ of women have completed primary school (PS), $20 \%$ of women have completed vocational school (VS), 31\% secondary school (SS) and $28 \%$ have post-secondary or tertiary education (hereinafter tertiary education - TE). In terms of education, it needs to be considered that in the older age groups, the share of women with lower formal levels of education is higher. In terms of age, $32 \%$ are $25-39$ years old, $34 \%$ are 40 $54,19 \%$ are $55-64$ and the remaining $15 \%$ are $65-74$ years old. Three quarters of the women are married or living in a de facto union and $11 \%$ are single. About $45 \%$ of women have children under 18 (hereinafter children). $26 \%$ of women are retired, $61 \%$ are in active employment and the remaining percentages are students, housewives and unemployed women. More than $38 \%$ of women said they belong to the lowest or working class, $51 \%$ to the middle class and $11 \%$ to the upper middle and upper class. $32 \%$ of the women polled live in towns, $44 \%$ in rural and $24 \%$ in a suburban environment. 22\% come from Western Slovenia, 31\% from Central and 47\% from Eastern Slovenia.

\subsection{Methodology}

The data in the survey has been weighed by gender, 10-year age groups and health regions. The data on the structure of the target population to be weighed (residents of Slovenia aged 25-74 on 30 June 2008, separated by the above-mentioned variables) was obtained from the website of the Slovenian Statistical Office. The sample is not weighed by education.

The chosen independent variables are: education, age, community type, region of residence, the presence of a partner and children and self-perceived social class (8-10). The dependent variables were typical health- 
related behaviours. For each of them (where this was possible), the average target values for the population for an individual health-related behaviour is stated. For the sake of the survey, these values were determined using references $(27,32-34)$ :

- the frequency of eating breakfast during weekdays, average target value 3.5 or more on a four-stage scale;

- the frequency of the consumption of fresh fruit and vegetables, average target value 5 or more on a six-stage scale;

- the frequency of the consumption of red meat, average target value 4 or more on a six-stage scale;

- the frequency of consumption of flavoured nonalcoholic beverages, average target value 4 or more on a six-stage scale;

- the habit of adding salt to food, average target value 1.75 and more on a two-stage scale;

- the frequency of recreational and moderately intense physical activity and walking per week, average target value 3 or more and 4 or more respectively on a seven-stage scale;

- physical activity during the holidays, average target value 2.5 or more on a three-stage scale;

- total sleep time in a day during weekdays, average target value 2.75 or more on a fourstage scale.

The chosen dependent variables possess an ordinal scale of measurement and measure in the same direction. We were therefore able to calculate their average values for different demographic groups with 95\% confidence intervals for average and standard deviation where this was sensible. We also calculated $p$-values for differences in the average values between individual groups of women, e.g. within the same educational group. The Wald test was performed to show whether all the coefficients in the model, where the differences in the average values with regard to education and another demographic variable are verified, equal zero. A $p$-value of $p \leq 0.05$ was set for the significance level, unless stated otherwise. In the case of the Wald test, this means that the average values are approximately equal in consideration of two variables at a time. Furthermore, the model also includes calculated differences for the averages between different educational categories and other demographic variables and $p$-values were obtained for these calculations on the basis of multiple comparisons. In order to show the common characteristics of the selected health-related behaviour factors in individual subgroups of women, we used a hierarchical classification into homogenous groups formed by Ward's method. Similarities between the units were measured using squared Euclidean distance. The optimum number of groups was determined by a dendrogram, the drop in the value of the criteria function and knowledge of the surveyed content $(35,36)$. The percentage of missing values for the selected healthrelated behaviour variables was from $0.4 \%$ to $6.4 \%$, excluding the questions on physical activity, where the percentages were higher and thus not included in the classification.

IBM SPSS 19 and R 2.15.0 were used for data preparation and analysis.

\section{RESULTS}

The description of the results first shows the total average value, the standard deviation for individual dependent variables, the average values for individual educational groups, statistical significance and the confidence interval for the average (Table 1, where the dependent variables possess an ordinal scale of measurement and measure in the same direction, whereby 1 always means the least favourable value for the variable). For each health-related behaviour variable, the differences between the educational groups are described on the basis of the model described in the methodology section and in consideration of specific other demographic and socioeconomic variables (age, community type, region of residence, the presence of a partner and children under 18 and self-perceived social class), which is shown in Table 2. Table 2 shows the simultaneous effect of two socio-demographic factors (education and one of the independent variables) on each dependent variable. The descriptions emphasise only the most important statistically significant differences and those educational groups of women with the highest or lowest average values in an individual dependent variable. The individual significant differences or peculiarities have been charted. The final part is the presentation of the results of the hierarchical grouping of the respondents into homogeneous groups that enable a simultaneous insight into all treated health-related behaviour factors. 
Table 1. The total average values and standard deviations and the average values for individual educational groups for individual dependent variables. $P$-values have been added in order to determine statistical significance and confidence intervals.

Tabela 1. Skupne povprečne vrednosti in standardne deviacije ter povprečja po posameznih izobrazbenih skupinah za posamezne odvisne spremenljivke; dodane so $p$ vrednosti za opredelitev statistične značilnosti in intervali zaupanja.

\begin{tabular}{|c|c|c|c|c|c|c|c|c|c|}
\hline \multirow[t]{2}{*}{$\begin{array}{l}\text { Dependent variables"*** } \\
\text { Odvisne spremenljivke }\end{array}$} & \multirow{2}{*}{$\begin{array}{l}\text { Total } \\
\text { average } \\
\text { Skupno } \\
\text { povprečje }\end{array}$} & \multirow{2}{*}{$\begin{array}{l}\text { Standard } \\
\text { deviation } \\
\text { Standardna } \\
\text { deviacija }\end{array}$} & \multicolumn{4}{|c|}{$\begin{array}{l}\text { Average by educational groups } \\
\text { Povprečje glede na izobrazbeno } \\
\text { skupino }\end{array}$} & \multirow[b]{2}{*}{$p$} & \multicolumn{2}{|c|}{$\begin{array}{l}95 \% \text { Confidence } \\
\text { interval } \\
\text { Interval zaupanja } \\
\end{array}$} \\
\hline & & & PS & VS & SS & TE & & \begin{tabular}{c|} 
Lower \\
endpoint \\
Spodnji
\end{tabular} & $\begin{array}{l}\text { Upper } \\
\text { endpoint } \\
\text { Zgornji }\end{array}$ \\
\hline $\begin{array}{l}\text { Self-assessed care for own health } \\
\text { Samoocenjena skrb za zdravje } \\
\text { (Scale from } 1 \text { to } 4 \text { ) }\end{array}$ & 2.68 & 0.62 & 2.63 & 2.61 & 2.67 & 2.77 & $\star \star \star *$ & 2.66 & 2.70 \\
\hline $\begin{array}{l}\text { Experiencing stress } \\
\text { Doživljanje stresa } \\
\text { (Scale from } 1 \text { to } 5)\end{array}$ & 2.89 & 0.84 & 2.97 & 2.92 & 2.89 & 2.82 & $\star \star * *$ & 2.87 & 2.92 \\
\hline $\begin{array}{l}\text { Stress management } \\
\text { Obvladovanje stresa } \\
\text { (Scale from } 1 \text { to } 5 \text { ) }\end{array}$ & 3.86 & 0.70 & 3.73 & 3.85 & 3.88 & 3.95 & 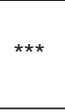 & 3.84 & 3.88 \\
\hline $\begin{array}{l}\text { Frequency of eating breakfast } \\
\text { Pogostost uživanja zajtrka } \\
\text { (Scale from } 1 \text { to 4) }\end{array}$ & 3.14 & 1.16 & 3.28 & 3.04 & 3.06 & 3.21 & $\star \star \star *$ & 3.11 & 3.18 \\
\hline $\begin{array}{l}\text { Frequency of consumption of fruit } \\
\text { Pogostost uživanja sadja } \\
\text { (Scale from } 1 \text { to } 6 \text { ) }\end{array}$ & 4.76 & 1.25 & 4.56 & 4.75 & 4.79 & 4.91 & $\star \star \star *$ & 4.73 & 4.80 \\
\hline $\begin{array}{l}\text { Frequency of consumption of vegetables } \\
\text { Pogostost uživanja zelenjave } \\
\text { (Scale from } 1 \text { to } 6 \text { ) }\end{array}$ & 4.62 & 1.08 & 4.52 & 4.66 & 4.63 & 4.65 & * & 4.59 & 4.65 \\
\hline $\begin{array}{l}\text { Frequency of consumption of red meat } \\
\text { Pogostost uživanja rdečega mesa } \\
\text { (Scale from } 1 \text { to } 6 \text { ) }\end{array}$ & 3.44 & 0.83 & 3.31 & 3.41 & 3.47 & 3.51 & $\star \star * *$ & 3.41 & 3.46 \\
\hline $\begin{array}{l}\text { Frequency of consumption of flavoured non- } \\
\text { alcoholic beverages } \\
\text { Pogostost uživanja brezalkoholnih } \\
\text { aromatiziranih pijač } \\
\text { (Scale from } 1 \text { to } 6 \text { ) }\end{array}$ & 3.79 & 1.26 & 3.59 & 3.69 & 3.84 & 3.96 & $* * *$ & 3.75 & 3.83 \\
\hline $\begin{array}{l}\text { The habit of adding salt to food } \\
\text { Dosoljevanje hrane } \\
\text { (Scale from } 1 \text { to } 2 \text { ) }\end{array}$ & 1.57 & - & 1.54 & 1.57 & 1.58 & 1.59 & - & 1.56 & 1.59 \\
\hline $\begin{array}{l}\text { Recreational and moderately intense physical } \\
\text { activity } \\
\text { Rekreativna zmerno intenzivna telesna } \\
\text { dejavnost } \\
\text { (Scale from } 1 \text { to } 7 \text { ) }\end{array}$ & 2.5 & 2.01 & 2.38 & 2.27 & 2.69 & 2.45 & ** & 2.41 & 2.59 \\
\hline $\begin{array}{l}\text { Recreational walking } \\
\text { Rekreativna hoja } \\
\text { (Scale from } 1 \text { to } 7 \text { ) }\end{array}$ & 3.94 & 2.30 & 4.21 & 3.97 & 4.08 & 3.67 & $\star \star \star *$ & 3.85 & 4.03 \\
\hline $\begin{array}{l}\text { Physical activity during the holidays } \\
\text { Telesna dejavnost med počitnicami } \\
\text { (Scale from } 1 \text { to } 3 \text { ) }\end{array}$ & 2.27 & 0.68 & 2.18 & 2.19 & 2.28 & 2.39 & $\star \star * *$ & 2.25 & 2.29 \\
\hline $\begin{array}{l}\text { Total sleep time per weekday } \\
\text { Skupni čas spanja med delavnikom } \\
\text { (Scale from } 1 \text { to } 4 \text { ) }\end{array}$ & 2.39 & 0.80 & 2.42 & 2.40 & 2.36 & 2.41 & - & 2.37 & 2.42 \\
\hline \multicolumn{10}{|c|}{$\begin{array}{l}\text { PS - primary school; VS - vocational school; SS - secondary school; TE - post-secondary or tertiary education } \\
{ }^{*} \mathrm{p}<0.05,{ }^{* *} p<0.01,{ }^{* * *} p<0.001 \\
\text { favourable value for the variable } \\
\text { Grey fields - inversely proportional connection between the variable and education }\end{array}$} \\
\hline
\end{tabular}


Table 2. Statistically significant differences in health-related behaviour factors by education while considering other demographic and socioeconomic variables.

Tabela 2. Statistično značilne razlike v dejavnikih življenjskega sloga glede na izobrazbo, hkratno upoštevajoč druge demografske in socialno ekonomske spremenljivke.

\begin{tabular}{|c|c|c|c|c|c|c|}
\hline $\begin{array}{l}\text { EDUCATION + } \\
\text { IZOBRAZBA + }\end{array}$ & $\begin{array}{l}\text { age } \\
\text { starost }\end{array}$ & $\begin{array}{l}\text { community } \\
\text { type } \\
\text { tip naselja }\end{array}$ & $\begin{array}{l}\text { region of } \\
\text { residence } \\
\text { regija } \\
\text { bivanja }\end{array}$ & $\begin{array}{l}\text { presence } \\
\text { of a child } \\
\text { prisotnost } \\
\text { otroka }\end{array}$ & $\begin{array}{l}\text { presence of } \\
\text { a partner } \\
\text { prisotnost } \\
\text { partnerja }\end{array}$ & $\begin{array}{l}\text { social } \\
\text { class } \\
\text { socialni } \\
\text { razred }\end{array}$ \\
\hline $\begin{array}{l}\text { Care for own health } \\
\text { Samoocenjena skrb za zdravje }\end{array}$ & * & * & * & * & * & * \\
\hline $\begin{array}{l}\text { Experiencing stress } \\
\text { Doživljanje stresa }\end{array}$ & * & * & * & * & * & * \\
\hline $\begin{array}{l}\text { Stress management } \\
\text { Obvladovanje stresa }\end{array}$ & * & * & * & * & * & * \\
\hline $\begin{array}{l}\text { Frequency of eating breakfast } \\
\text { Pogostost uživanja zajtrka }\end{array}$ & * & * & * & * & * & * \\
\hline $\begin{array}{l}\text { Frequency of consumption of fruit } \\
\text { Pogostost uživanja sadja }\end{array}$ & * & * & * & * & * & * \\
\hline $\begin{array}{l}\text { Frequency of consumption of vegetables } \\
\text { Pogostost uživanja zelenjave }\end{array}$ & * & * & * & & * & * \\
\hline $\begin{array}{l}\text { Frequency of consumption of red meat } \\
\text { Pogostost uživanja rdečega mesa }\end{array}$ & * & * & * & * & * & * \\
\hline $\begin{array}{l}\text { Frequency of consumption of flavoured non- } \\
\text { alcoholic beverages } \\
\text { Pogostost uživanja brezalkoholnih } \\
\text { aromatiziranih pijač }\end{array}$ & * & * & * & * & * & * \\
\hline $\begin{array}{l}\text { Adding salt to food } \\
\text { Dosoljevanje hrane }\end{array}$ & * & * & * & * & & \\
\hline $\begin{array}{l}\text { Recreational and moderately intense physical } \\
\text { activity } \\
\text { Rekreativna zmerno intenzivna telesna } \\
\text { dejavnost }\end{array}$ & * & * & * & * & * & * \\
\hline $\begin{array}{l}\text { Recreational walking } \\
\text { Rekreativna hoja }\end{array}$ & * & * & * & * & * & * \\
\hline $\begin{array}{l}\text { Physical activity during the holidays } \\
\text { Telesna dejavnost med počitnicami }\end{array}$ & * & * & * & * & * & * \\
\hline $\begin{array}{l}\text { Total sleep time per weekday } \\
\text { Skupni čas spanja med delavnikom }\end{array}$ & * & & & & & * \\
\hline${ }^{*} p<0.05$ & & & & & & \\
\hline
\end{tabular}

\subsection{Self-assessed care for own health and education in women}

On average, women estimate that they take rather good care of their health. In general, women with a higher educational attainment stand out followed by women with secondary education, primary education and vocational education (Table 1). Women with vocational and primary education aged 40 to 54 take the least care of their health. In general, women in a rural environment take less care of their health regardless of their education and women in an urban environment more. Women with tertiary education in a rural environment take the same care of their health as women with primary and vocational education in towns (Figure 1, Table 2). 


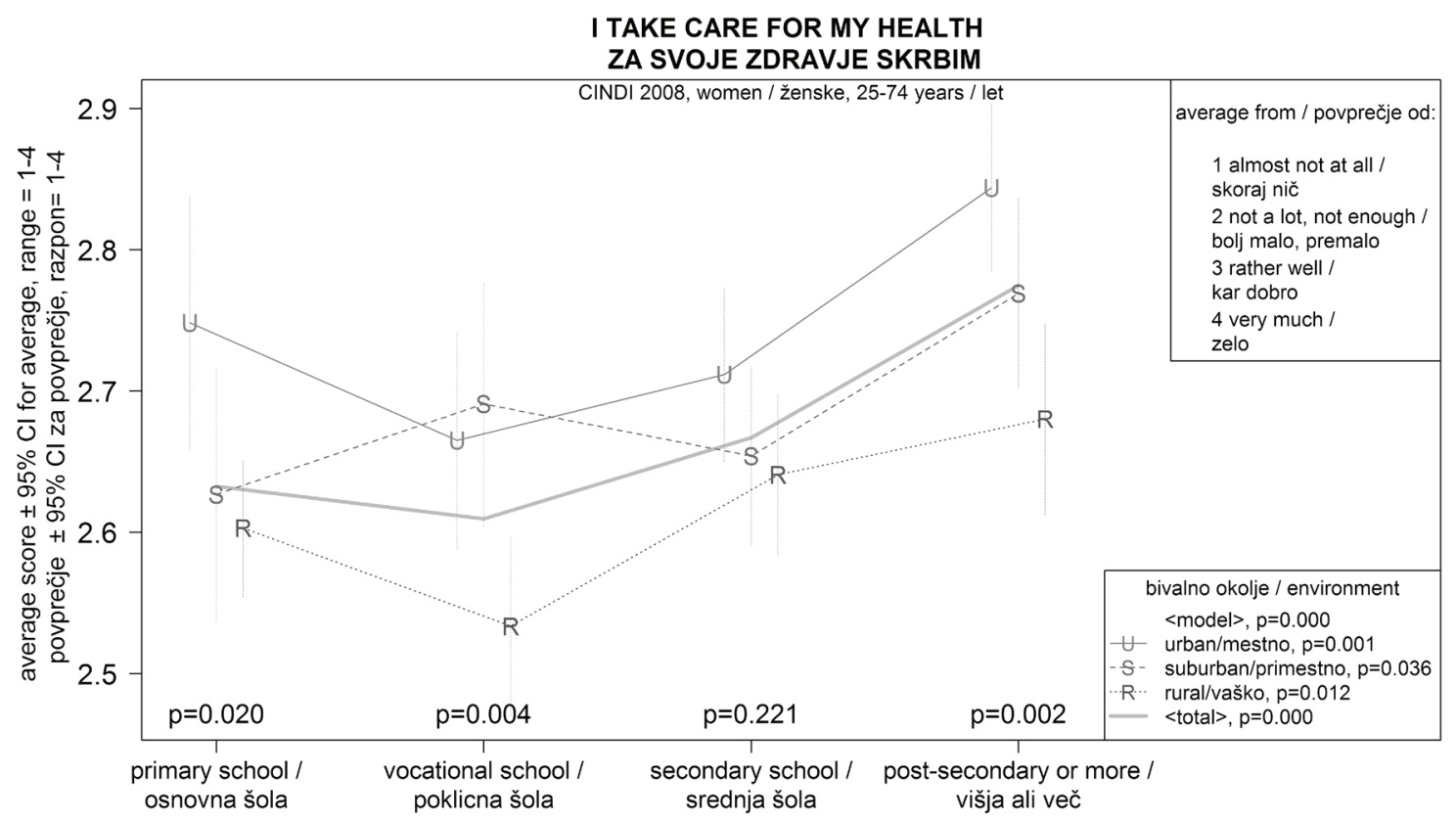

Figure 1. Level of caring for own health in women by educational attainment and community type.

Slika 1. Stopnja skrbi za svoje zdravje pri ženskah, glede na izobrazbo in tip naselja.

The most distinct differences in taking care of own health among the educational groups can be found in Eastern Slovenia, while there are no significant differences between the educational groups in Western Slovenia. With the exception of women with primary education, all women take less care of their health if they have children. (Figure 2, Table 2). Women with secondary or tertiary education take less care of their health if they are living with a partner. Regardless of education, they take equal and the least care of all the classes if they classified themselves as belonging to the lowest or working class (Table 2).

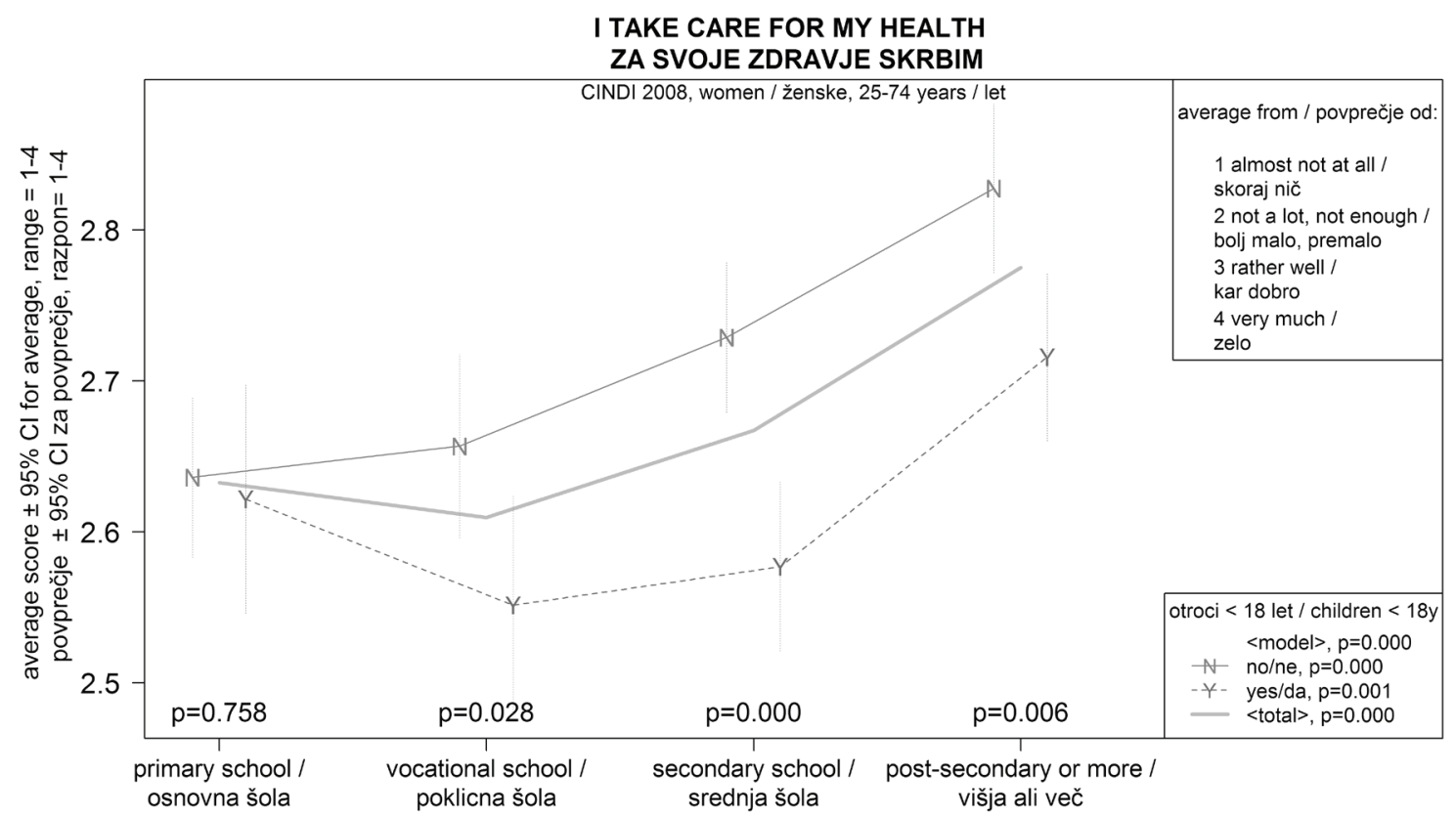

Figure 2. Level of caring for own health in women by educational attainment and children.

Slika 2. Stopnja skrbi za svoje zdravje pri ženskah, glede na izobrazbo in otroke. 


\subsection{Stress and the effect of education in women}

On average, women experience stress occasionally and manage it relatively easily. While the frequency of experiencing stress increases with the level of educational attainment, the difficulty of managing stress decreases with increasing levels of educational attainment. Stress exposure is thus most common among more educated women, who however manage it the easiest. Women with primary and lower education have the most difficulties managing stress even though they experience it the least often (Table 1). In all educational groups, stress is most commonly and most difficultly managed by women aged 40 to 54 . In this age group, stress is most commonly experienced by women with a higher educational attainment and managed with the most difficulty by women with primary education (Table 2).

The differences in experiencing stress with regard to community type are especially evident in women with a higher educational attainment, as those who live in a rural environment experience stress substantially more often than equally educated women who live in other environments - at the same time the most frequently of all women. Women with primary education who live in the suburbs or in the rural environment experience stress the least frequently (Figure 3 ). In terms of stress management, it was established that women living in a rural environment manage stress worse than women living in an urban or suburban area in all levels of education with the exception of primary education where the situation is reversed (Table 2).

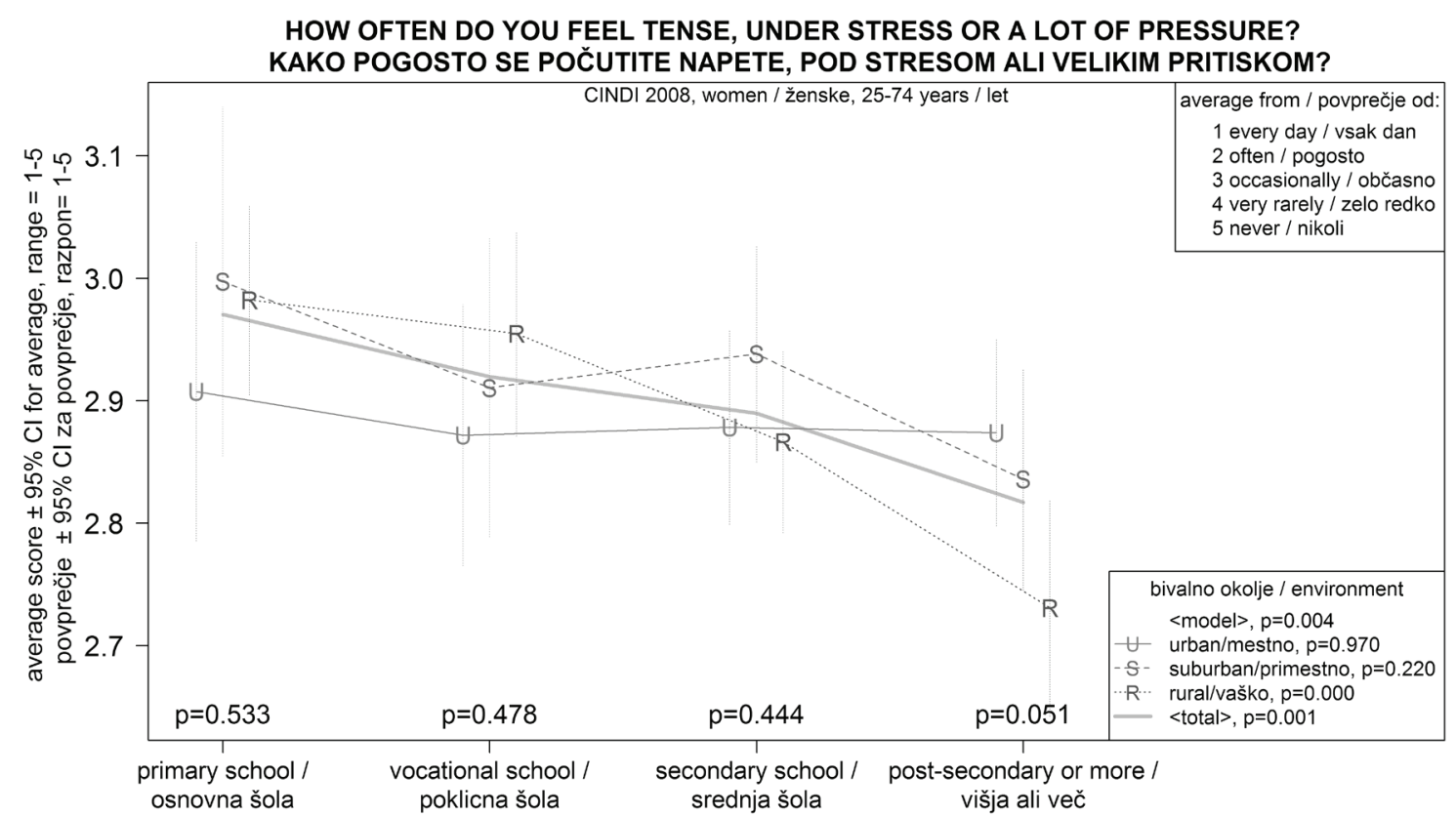

Figure 3. Stress exposure in women by educational attainment and community type.

Slika 3. Izpostavljenost stresu, pri ženskah, glede na izobrazbo in tip naselja.

Regardless of education, stress is most frequent and more poorly managed by women living in the eastern part of Slovenia. Women with primary education living in the east thus experience stress substantially more often and manage it substantially worse than equally educated women in Western Slovenia. However, a woman with tertiary education living in Eastern Slovenia experiences stress with an approximately equal frequency and manages it with approximately equal difficulty as a woman with a primary education from Western Slovenia (Table 2).
Regardless of education, women with children experience stress more frequently and also manage it better across the majority of educational groups. Among them, stress is most frequently experienced by women with a higher educational attainment (Table 2). Women who belong to the lowest and working class are most fraught with stress, as they experience it most frequently and also have the greatest difficulties managing it. On the other hand, middle class women experience stress least frequently and stress management is generally best in women from the upper middle and upper class. 
Women from the lowest or working class with a higher educational attainment manage stress substantially better than less educated women from the same class (Table 2).

\subsection{Nutrition and education in women}

With regard to the average values of indicators of healthy eating, women do not achieve the recommended target values for any of the reviewed behavioural patterns. However, they are on average only slightly below the target average for all of them (Table 1). A review of eating habits shows that in general, healthier eating habits can be observed among women with a higher educational attainment who eat breakfast more frequently, consume fruit and vegetables more frequently and consume red meat and flavoured nonalcoholic beverages less often (Table 1).

Older women from all educational groups eat breakfast more frequently and add salt to their food the least frequently, while on the other hand red meat is most frequently consumed by older women with vocational education. Regardless of education, flavoured nonalcoholic beverages are most frequently consumed by the youngest group of women, who also consume fruit and vegetables the least frequently in almost all the educational groups. In general, younger women also rarely eat breakfast and the frequency of eating breakfast in this group is only higher in women with a higher educational attainment.

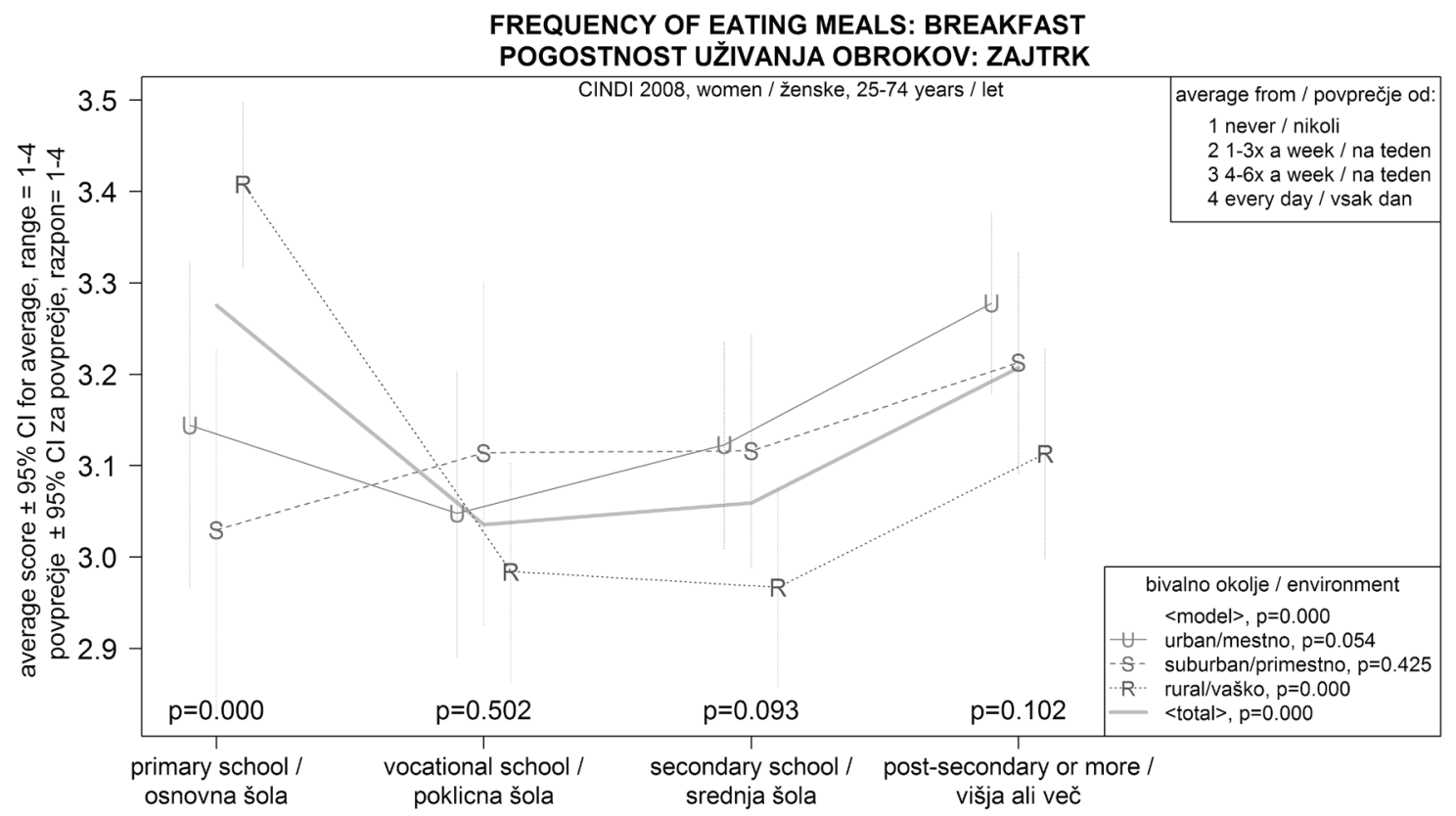

Figure 4. he frequency of eating breakfast in women by educational attainment and community type.

Slika 4. Pogostost uživanja zajtrka ženskah, glede na izobrazbo in tip naselja.

In terms of the frequency of eating breakfast, in addition to women with a higher educational attainment, women with primary education also eat breakfast frequently, especially women from the rural environment (Figure 4). In terms of the frequency of eating breakfast, fruit and red meat, rural women with a higher educational attainment do not differ from women with primary education from the urban environment. Women from the rural environment in all educational groups eat red meat most frequently (Figure 5). Flavoured nonalcoholic beverages are most frequently consumed by rural women with vocational and secondary education. In Eastern Slovenia, fruit is most frequently consumed by women with a higher educational attainment, while vegetables are most frequently consumed by women with a higher educational attainment living in Western Slovenia. In Central and Eastern Slovenia, flavoured non-alcoholic beverages are most frequently consumed by women with a lower educational attainment.

Women with children eat breakfast and consume fruit less frequently and more frequently add salt to their food than women who do not have children. The lowest frequency of eating breakfast and consuming fruit can be found among women with a secondary education who have children and the most frequent addition of 
salt to food is among women with a primary education who have children. Women with a higher educational attainment who have children eat breakfast as frequently as women with vocational education who do not have children. Women with children more frequently consume flavoured non-alcoholic beverages, which applies to all educational groups with the exception of the group with tertiary education. The presence of children and a partner also increases the frequency of consuming red meat to a certain extent.

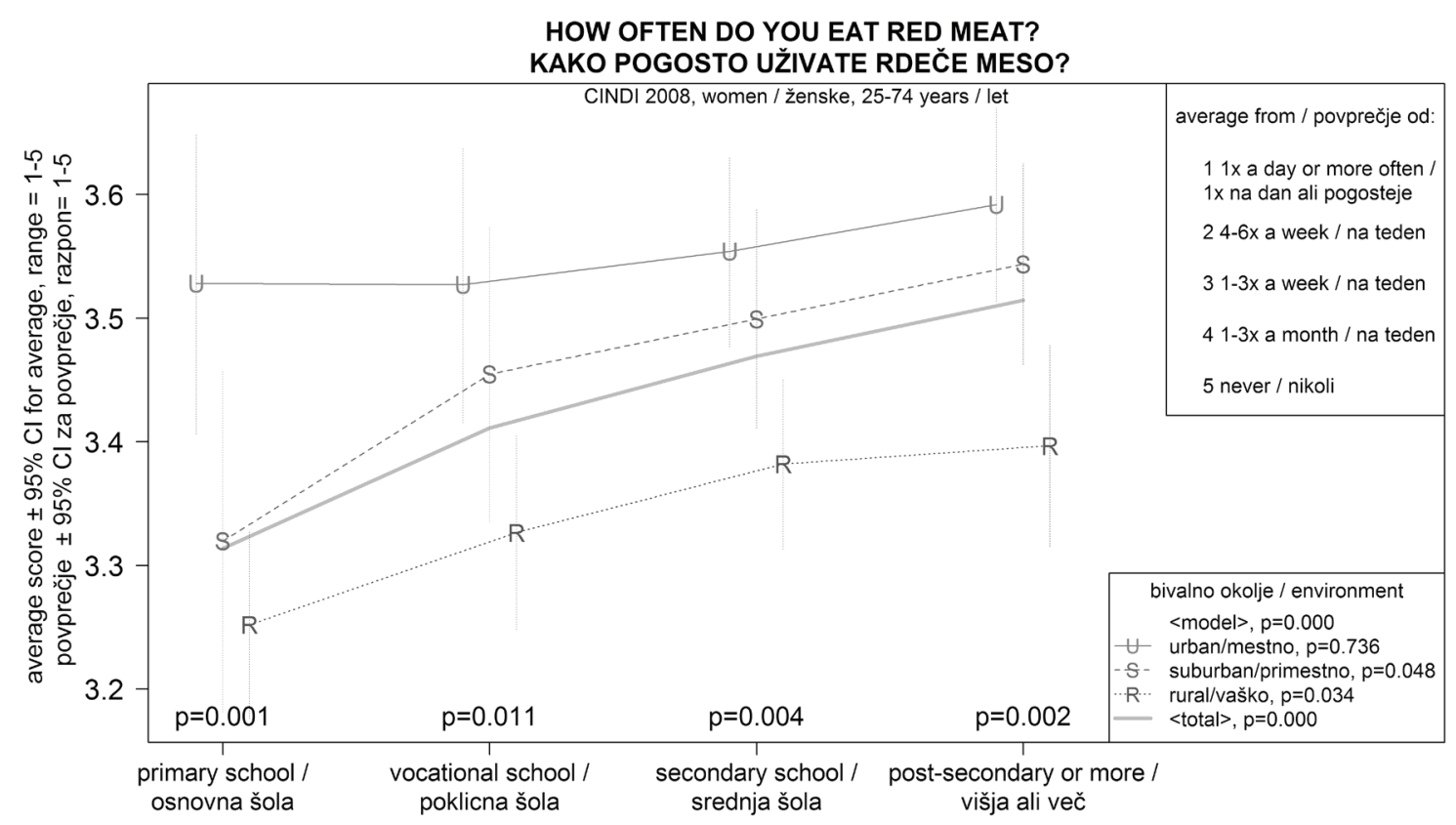

Figure 5. The frequency of eating red meat in women by educational attainment and community type.

Slika 5. Pogostost uživanja rdečega mesa pri ženskah, glede na izobrazbo in tip naselja.

\subsection{Moderately intense physical activity for health and education in women}

On average, women are moderately physically active 2.5 days a week, while walking as a form of exercise is done almost 4 days a week. During the holidays, women are at least occasionally physically active on average. Moderately intense recreation is most frequently present among women with secondary and tertiary education and more rarely among women with primary and vocational education. Women with a primary education walk most frequently as a form of exercise and women with a tertiary education the least frequently. Physical activity during the holidays increases with the attained educational level (Table 1).

Considering the age and the studied forms of activity, older women are the most active: moderate physical activity is most frequently present among women with a secondary education over the age of 55 , while women with the same educational attainment from the oldest group most frequently engage in recreational walks. Among women with secondary and tertiary education, substantially more engage in moderate physical activity (including recreational walks) in Eastern Slovenia, while women with primary and vocational education from Eastern Slovenia are significantly less moderately active than women with a higher educational attainment. In our survey, women with a higher educational attainment from Eastern Slovenia are the most physically active of all women with a higher educational attainment and the least frequent pursuit of recreational walking is practiced by women with a higher educational attainment in Western Slovenia (Figure 6). In the urban environment, the most frequent recreational walks are undertaken by women with primary education, while physical activity during the holidays shows that regardless of community type, women with a higher educational attainment are the most active in all environments.

Children affect the physical activity of women. Among all educational groups, women with secondary education who do not have children engage in moderate physical activity the most frequently, including recreational walking. Regardless of education, women who see themselves as part of the lowest social class engage in recreational walks the most (Table 2). 


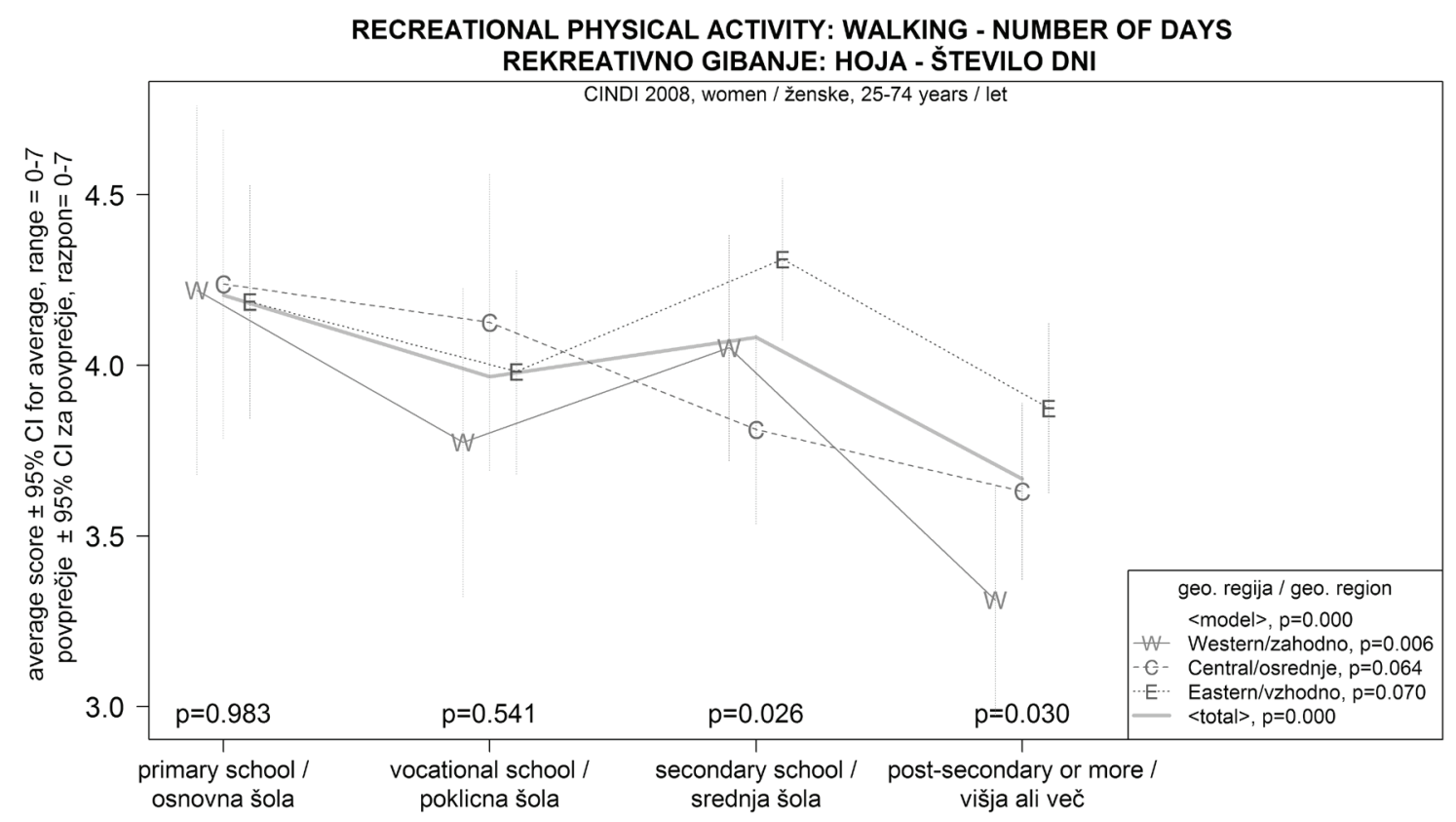

Figure 6. Recreational walking in women by educational attainment and region of residence.

Slika 6. Rekreativna hoja pri ženskah, glede na izobrazbo in regijo bivanja.

\subsection{Total sleep time and education in women}

Women state that they usually sleep an average of 6 to 8 hours a day. In terms of education, no differences were noted in general (Table 1). In the age groups, the fewest hours of sleep belong to middle-aged women with a primary education and the most to younger women with a higher educational attainment. Among the individual educational groups, only women with a higher educational attainment and with children from Central Slovenia reported a lower number of hours of sleep. However, fewer hours of sleep were also reported by women with secondary education from the suburban environment. In terms of hours of sleep per day, the education variable distinguishes women who see themselves as coming from the lowest and working class and within this subgroup, women with a secondary education are receiving the least sleep (Table 2).

\subsection{Classification into homogeneous groups}

The respondents sample was classified into four homogeneous groups with the help of statistical and content criteria (Table 3). 
Table 3. The classification of women into four homogeneous groups by chosen health-related behaviour variables; Ward's method.

Tabela 3. Razvrstitev žensk v štiri homogene skupine glede na izbrane spremenljivke življenjskega sloga, po Wardovi metodi.

\begin{tabular}{|c|c|c|c|c|}
\hline & \multicolumn{4}{|c|}{$\begin{array}{l}\text { Four homogeneous groups } \\
\text { Štiri homogene skupine }\end{array}$} \\
\hline & $\begin{array}{l}\text { Group } 1 \\
\text { Skupina } 1\end{array}$ & $\begin{array}{l}\text { Group } 2 \\
\text { Skupina } 2\end{array}$ & $\begin{array}{l}\text { Group } 3 \\
\text { Skupina } 3\end{array}$ & $\begin{array}{l}\text { Group } 4 \\
\text { Skupina } 4\end{array}$ \\
\hline $\begin{array}{l}\text { How do you take care of your health? } \\
\text { Kako skrbite za svoje zdravje? }\end{array}$ & ++ & + & - & - \\
\hline $\begin{array}{l}\text { How often do you feel tense, under stress or a lot of } \\
\text { pressure? } \\
\text { Kako pogosto se počutite napete, pod stresom ali } \\
\text { velikim pritiskom? }\end{array}$ & ++ & + & 0 & - \\
\hline $\begin{array}{l}\text { How do you manage tension, stress and pressure that } \\
\text { you experience? } \\
\text { Kako obvladujete napetosti, strese in pritiske, ki jih } \\
\text { doživljate v življenju? }\end{array}$ & ++ & + & 0 & - \\
\hline $\begin{array}{l}\text { How many hours do you usually sleep on weekdays? } \\
\text { Koliko ur na dan med delovnim tednom običajno spite? }\end{array}$ & 0 & 0 & + & - \\
\hline $\begin{array}{l}\text { How often do you eat breakfast? } \\
\text { Kako pogosto uživate zajtrk? }\end{array}$ & +++ & ++ & ++ & - - - \\
\hline $\begin{array}{l}\text { How often do you eat fresh fruit? } \\
\text { Kako pogosto uživate sveže sadje? }\end{array}$ & ++ & ++ & 0 & - - \\
\hline $\begin{array}{l}\text { How often do you eat fresh vegetables? } \\
\text { Kako pogosto uživate svežo zelenjavo? }\end{array}$ & ++ & ++ & 0 & - - \\
\hline $\begin{array}{l}\text { How often do you eat red meat? } \\
\text { Kako pogosto uživate rdeče meso? }\end{array}$ & + & 0 & - & 0 \\
\hline $\begin{array}{l}\text { How often do you consume flavoured carbonated and } \\
\text { non-carbonated non-alcoholic beverages? } \\
\text { Kako pogosto uživate aromatizirane gazirane in } \\
\text { negazirane brezalkoholne pijače? }\end{array}$ & +++ & ++ & - - - & 0 \\
\hline $\begin{array}{l}\text { Do you add salt to your food at the table? } \\
\text { Ali hrano pri mizi dodatno solite? }\end{array}$ & +++ & - - - & + & 0 \\
\hline $\begin{array}{l}\text { How physically active are you during the holidays? } \\
\text { Koliko ste telesno dejavni med počitnicami? }\end{array}$ & ++ & + & - & - \\
\hline $\begin{array}{l}\text { Key to deviations from the average in the positive and nega } \\
\text { od povprečja v pozitivno oziroma negativno smer, za posa } \\
\text { Two-stage scale/Dvostopenjska lestvica: } 0-0.05=0 ; 0.06 \\
\text { Three-stage scale/Trostopenjska lestvica: } 0-0.10=0 ; 0.1 \\
\text { Four-stage scale/Štiristopenjska lestvica: } 0-0.10=0 ; 0.11 \\
\text { Five-stage scale/Petstopenjska lestvica: } 0-0.05=0 ; 0.06 \\
\text { Six-stage scale/Šeststopenjska lestvica: } 0-0.09=0 ; 0.10\end{array}$ & $\begin{array}{l}\text { Iive direction fo } \\
\text { Imezno odvisno } \\
6-0.20=+/-; 0 \\
1-0.20=+/-; 0 \\
1-0.25=+/-; 0 \\
-0.15=+/-; 0 \\
-0.29=+/-; 0 .\end{array}$ & $\begin{array}{l}\text { dividual depe } \\
\text { remenljivko: } \\
-0.40=++/- \\
-0.40=++/- \\
-0.60=++/- \\
-0.25=++/-\end{array}$ & $\begin{array}{l}\text { nt variable / L } \\
\text { lore than/več } \\
\text { lore than/več } \\
\text { lore than/več } \\
\text { ore than/več } \\
\text { ore than/več }\end{array}$ & $\begin{array}{l}\text { nda odstopo } \\
0.40=+++/-- \\
0.40=+++/-- \\
0.60=+++-- \\
0.25=+++-- \\
0.69=+++--\end{array}$ \\
\hline
\end{tabular}


In the first group, there are $22 \%$ of women with the highest level of educational attainment of all four groups. Their average age is 50.19 years, with the majority being over 55 years old. Two thirds of them do not have children under 18. Significantly more often than women in other groups, they live in towns and in Western and Central Slovenia. Significantly more often than the total sample, they classified themselves as belonging to the upper middle and upper class. They take good care of their health, do not often feel under stress and also manage stress rather well. They eat breakfast and fruit practically every day but eat vegetables slightly less often. They consume red meat in accordance with the recommendations and one tenth do not eat red meat at all. Almost two thirds never consume flavoured non-alcoholic beverages and those who do, consume them rarely. Practically all said that they never add salt to food at the table. During the holidays, a rather high share is regularly physically active and they sleep the same number of hours as the average of all the surveyed women.

In the second group, there are $19 \%$ of women who also have a higher educational attainment than the average level. Their average age is 48.81 years, with the majority being in the over 45 to 64 age groups. More than half do not have underage children. Significantly more often than women in other groups, they live Central Slovenia and in towns. Women in the second group also classified themselves as belonging to the upper middle and upper class significantly more often than the total sample. They take slightly less care of their health, with one quarter believing that they do not take sufficient care of their health. They feel that they are under stress slightly more often than the first group but still manage it relatively well. They eat breakfast rather frequently and a large share eats fruit every day. They eat vegetables slightly less frequently. On average, they consume red meat frequently. They consume flavoured non-alcoholic beverages slightly more often than the first group and practically all add salt to their food either after tasting it or not. During the holidays, one half of them are regularly physically active and they sleep the same number of hours as the average of all the surveyed women.

In the third group, there are $18.5 \%$ of women with completed primary education, a significantly higher share compared to the other groups. The average age is 47.76 years and compared to other groups, the majority belong to the youngest and to some extent to the oldest age groups. A higher share than in the first and second group have underage children and more often than all other groups live in a rural environment in Eastern
Slovenia and classify themselves as belonging to the lowest and working class. Almost one half take little care of their health or not at all. On average, they feel under stress and they also manage it like the average of all the surveyed women. They regularly eat breakfast and less frequently consume fruit and vegetables. In this respect, they are average. They consume red meat more frequently than recommended and $15 \%$ of women from this group consume it every day or 4 to 6 times a week. They consume flavoured non-alcoholic beverages substantially more frequently than other groups of women with over one quarter consuming them every day. Two thirds never add salt to their food. During the holidays, the highest share of all the groups mostly rest. They sleep slightly longer than the average of the surveyed women.

In the fourth group, there are $40.5 \%$ of women who, compared with other groups, most often have completed secondary school. More often than in other groups, they are middle-aged women in the 35 to 54 age groups with the average age being 46. A higher share than in other groups have underage children and significantly more often live in a rural environment in Central Slovenia and classify themselves as belonging to the lowest and working class. One half of them do not take sufficient care of their health or do not take care of their health at all. Among all the groups, the highest share feel under stress and more than one third feel it very often or every day. Of all the groups, they have the most difficulties managing stress. Two thirds rarely or never eat breakfast and are far below average. The same applies to the frequency of consuming fruit and vegetables. On average, they eat red meat frequently and the same applies to the consumption of flavoured non-alcoholic beverages and adding salt to food at the table. During the holidays, a slightly higher share mostly rest. They sleep the least number of hours per day of all four groups.

\section{DISCUSSION}

The results confirm our assumption that there are statistically significant differences between different educational groups in the individual health-related behaviour indicators. Even though these differences are mostly not very distinct or unambiguous, education can be seen as one of the protective factors of health and health-related behaviours (10). In our analysis, the group of women with post-secondary and tertiary education evaluates the majority of indicators more favourably than women in other educational groups. 
Other studies also indicate better results on average for women with a higher educational attainment, which can be explained by the fact that a higher educational attainment is as a rule connected to a better economic, cultural and social capital (37-38), which reduces material, psychological and behavioural risks relating to health while at the same time enabling better access to behavioural, material and psychosocial resources that have a positive relation to health (39-41). Women with a higher educational attainment are supposed to have more knowledge and skills, stronger social support and are supposedly also more motivated to control their life $(40,42)$. An indicative fact from our analysis is that women with a higher educational attainment are more exposed to stress but manage it more successfully, which can be attributed to better stress management possibilities.

Behaviour indicators in women with secondary, vocational and primary education show less favourable health effects than in women with post-secondary and tertiary education (10). However, the results show that the differences among women with a lower educational attainment are not very distinct. Furthermore, Slovenian women with the lowest educational attainment do not have the lowest values of health-related behaviour indicators on average and in some cases even stand out in health behaviour compared to other educational groups (the frequency of eating breakfast). Women with a lower educational attainment, who are more often part of the lower social class than women with a higher educational attainment, are predominantly more exposed to individual stressors and risk factors (e.g. loss of job, financial distress) that can act synergistically and thus enhance their risk exposure (18). At the same time, they also connect with other unfavourable healthrelated behaviour factors $(3,9-10)$. Unhealthy eating and activity habits, which are seen in the nutrition status as overweight and obesity, are seen to a greater extent in women with a lower educational attainment $(8,9,24)$ and over $40 \%$ of obesity in women can be attributed to differences in socioeconomic status (24).

Even though education has been proven to be a factor of differences, our data indicates that in some cases it is not the key factor. Health-related behaviour also differs with regard to other socio-demographic indicators and not only between differently but also between equally educated women. Women with a higher educational attainment living in a rural environment thus exhibit approximately the same behavioural patterns as women with primary and vocational education from the urban environment (care for own health, consumption of fruit and read meat and stress management). Women with a higher educational attainment living in Eastern Slovenia on average experience stress as frequently as women with primary education living in Western Slovenia. They also manage it with approximately equal difficulty. Women with a higher educational attainment who have children often exhibit less favourable behavioural patterns than less educated women without children. They are exposed to stress more, eat less healthily and are less physically active. In self-assessed care for own health, women who classify themselves as belonging to the lowest or working class evaluate their care for health the lowest regardless of their education. The finding that health-related behaviour differences are not unambiguously connected to differences in education is also confirmed by the classification into homogeneous groups. These indicate that the group with prevailingly tertiary educated women is divided into two different groups and that the group with a prevailingly lowest education does not have the worst health-related behaviour. This means that individual educational groups are not homogeneous and do not behave in a completely uniform manner but show different lifestyles, which blurs the distinct differences. This might partially explain why health differences by education are relatively small in Slovenia (43).

Our study does have some limitations. For example, it is based on the subjective evaluations of behaviour indicators and the criteria that the respondents used to evaluate these indicators are also subjective. Healthrelated behaviour is much more complex than our analysis shows and the same applies to the factors that affect it. The analysis thus does not include all health-related behaviours, such as risk behaviours (tobacco use, harmful alcohol use, illicit drugs), nor does it cover all socio-demographic characteristics. Furthermore, the sample includes $28 \%$ of respondents with post-secondary or tertiary education. According to the information of the Slovenian Statistical Office, this share is slightly more than $21 \%(44)$ in the total population over 24 . Nevertheless, our findings allow us to draw individual conclusions that are important for the development of policies on health or general public health systems, while at the same time providing some explanation for the previously relatively small differences in women's health by education.

After its independence, Slovenia to a certain extent preserved the elements of the past egalitarian political system with elements of solidarity such as universal basic health, social and educational system while at the same time implementing measures directed towards more vulnerable socioeconomic groups. This universal accessibility and availability of systemic measures for all is the key condition for reduced inequalities in health 
and health-related behaviours (10). Studies show that health inequalities are not merely a question of gaps in health between the richest and the poorest population group. The effects of the socioeconomic gradient in health can be seen in the entire population. The most efficient results can thus be achieved by comprehensive measures that are aimed at the entire population and, within those, especially at the ones with the lowest socioeconomic status $(3,10)$.

If out of the different socioeconomic and demographic factors (with the simultaneous effect of education), we choose only the effect of motherhood on health-related behaviour, we establish that women with children, regardless of education, more often have unhealthy eating habits, engage less in physical activity and experience more stress, which is probably related to problems with balancing their work and family life - the so-called double burden of women. Among women with children, women with tertiary education are most frequently exposed to stress. We presume that they perform more demanding and responsible tasks, highly value their employment and their own economic independence and also invest in their children's education (45). However, women with children, regardless of education, more often report experiencing stress than women without children, which can be connected to women with children being generally overwhelmed. Women in Slovenia still do the majority of the housework, they are absent from work in order to take care of a family member six times more often than men (45) and the aspirations of employers to continually improve their business performance indicators increase work pressure on women. Harmonising work with family life and taking care of children predominantly remains a private problem that parents or especially women have to handle themselves (46-47). Despite the rather well-regulated family policies in Slovenia, there are specific unfavourable practices in the field of childcare and family policies that place an additional strain on women: e.g. the unfavourable opening times of kindergartens (not harmonised with the parents' working hours), in many cases inaccessible and expensive childcare, only a few family-friendly companies, nonasserted family adapted work methods, etc. (45). In recent years, we have also been seeing a deterioration in employment opportunities, unreliable employment, increasing unemployment rates, changes to or even the abolishment of individual rights stemming from family policy, which can lead to financial distress for families and consequently to a deterioration of living conditions that affect the health of the entire family (48-49). It can be presumed that they can also lead to a deterioration of women's health-related behaviour and in the long run also health results and disease burden.

It needs to be considered that in 2008, when the study was implemented, Slovenia had the highest income equality, which was probably mostly due to the efficient system of social transfers and poverty would have been much higher had they not been in place (50). In the last quarter of 2008, Slovenia began experiencing the consequences of the global crisis, which have increased in recent years reflecting themselves in an economic, social and financial crisis. In times of crisis, there is a danger that the systems of public health and education and social assistance might be reformed in a manner increasing social inequalities by greatly transferring the care for health, education, childcare and social security from the state to individuals (28). In addition, subsidies are being reduced and abolished together with supports and universal programmes that used to perform the protective and corrective function and reduce inequalities and the network of public health and public education is being limited. Such reforms can also affect the deterioration of health-related behaviour indicators and health results, especially in those individuals who were seen to be more vulnerable - women with a lower educational attainment, living in the rural environment, having children or classifying themselves as belonging to the lowest social class. There are more possibilities for the appearance of unjust health inequalities between individual socioeconomic and demographic groups $(3,10)$ and it may also happen that under such circumstances, education would not keep its role as an important protective factor. Under circumstances when anti-crisis measures in Slovenia (layoffs and salary reductions) significantly affect sectors that employ more actively employed women with tertiary education (e.g. $60 \%$ of the tertiary educated population in the public sector) (51), these measures might expose the group of women with a higher educational attainment to risk factors that were previously experienced by women with a lower educational attainment.

Our data shows that women with a higher educational attainment, especially women with children, already report experiencing stress most frequently. The mentioned risk factors would probably enhance this stress and at the same time limit access to resources that helped women manage this stress relatively successfully. Deliberations on such possible scenarios indicate the urgency of evaluating the eventual possible effects of planned political measures on health, as considering the recommendations of such evaluations might at least partially limit unfavourable health results in the future (52). 
The World Health Organisation (28) has found that in times of economic crisis, countries tend to reduce investments in health and determinants of health, which may lead to long-term deterioration of the population's health. Various studies indicate that the effects of the crisis are less distinct in countries with generally higher levels of social protection. It is thus important that in preparing political measures, their possible effects on health are evaluated and reasonably considered, as the population's health on a structural level depends more on the effect of practically all public policies from all sectors than on the operation of the healthcare system (52). Unjust health inequalities, which may be caused by various political measures, can also represent a significant financial burden for the society. It has thus been estimated in the case of the United Kingdom that the economic burden of health inequalities amounts to $9.5 \%$ of the GDP (6).

Investments in health and greater equality thus do not mean only financial investments but an economically more successful society and a better quality of life for individuals and local communities. Policies shape the living and working conditions and these conditions are the key determinants of health and a healthy lifestyle. It is thus of key importance for Slovenia to implement the Health in All Policies Approach, which sees better health as a key component of welfare and at the same time acts towards reducing gaps in health. In this way, we will be able to create healthy conditions and opportunities for the better health of everyone, including women.

\section{CONCLUSION}

It was established that (1) there are statistically significant differences between the different educational groups of women in individual health-related behaviour indicators, which are however mostly not very distinct nor unambiguous, (2) the differences within the same educational group of women are also affected by a number of other factors and (3) the differences in the observed health-related behaviour indicators in the total sample are relatively small. In principle, it still stands that a higher educational attainment means a healthier lifestyle. However, a higher educational attainment for women is not in itself a protective factor as at least the effects of the residential area, region of residence, motherhood and self-perceived social class need to be considered. At the same time, the differences in the health-related behaviour of women with the lowest levels of education are relatively blurred.

The relatively small differences in health-related behaviour and health between all the educational groups in Slovenia can (1) partially be explained by a non-uniform group of women with a higher educational attainment and the fact that the group of women with the lowest educational attainment does not have the worst health-related behaviour indicators, which affects the greater equality in lifestyle. (2) On the other hand, the well-established universal and goal-oriented family and childcare policies that have been implemented in Slovenia for decades also affect these results. Therefore, we need to strive to preserve and improve them at times of crisis. In preparing new measures, their possible effects on the increase of health differences in women need to be considered. Such policies and measures are more efficient if complex measures are being prepared and implemented that are aimed at several health-related behaviour factors simultaneously, as we have shown that equal or similar rules often apply to them.

In the future, in-depth quantitative and qualitative study of individual social factors influencing women's health-related behaviour in different educational groups is required. Only these results can serve as basis for targeted and efficient policies, measures and programmes on the social and individual level. It is especially important to use this data in the preparation of evaluations of the effects that individual proposed measures or programmes will have on health. It would be sensible to repeat a similar study at different time intervals that include more distinct effects of the crisis of political measures that were adopted due to crisis conditions. It would also be relevant to implement a similar analysis for men.

\section{Acknowledgements}

We thank Dr Leja Dolenc Grošelj for her advice in searching for literature on sleeping patterns for the needs of this article.

\section{References}

1. World Health Organization. Reducing risks, promoting healthy life: the world health report. Geneva: World Health Organization, 2002.

2. World Health Organization. Global health risks. Geneva: World Health Organization, 2009.

3. Buzeti T, Gabrijelčič Blenkuš M, Gruntar Činč M, Ivanuša M, Pečar J, Tomšič S et al. Health inequalities in Slovenia. Ljubljana: Inštitut za varovanje zdravja RS, 2011. Available September 13, 2012 from: http://www.ivz.si/publikacije?pi=3\&_3_Filename=attName. png\&_3_Mediald=2924\&_3_AutoResize=false\&pl=109-3.3.

4. Zurc J. Povezave med gibalno aktivnostjo in pojavnostjo bolečine v križu pri zdravstvenem osebju. Zdrav Var 2012; 51: 207-222. 
5. Mackenbach JP. Health inequalities: Europe in profile: expert report commissioned by the UK Presidency of the EU. Rotterdam: Erasmus University Medical Centre, 2006.

6. Mackenbach JP, Stirbu I, Roskam AJR, Schaap MM, Menvielle G, Leinsalu M, Kunst AE. Socioeconomic inequalities in health in 22 European countries. NEJM 2008; 358: 2468-2481.

7. Marmot M, Atkinson T, Bell J, Black C, Broadfoot $P$, Cumberlege $\mathrm{J}$ et al. Fair society, healthy lives: the Marmot review executive summary. The Marmot Review Team, 2010.

8. Boyland S, Lallukka T, Lahelma E, Pikhart H, Malyutina S, Pajak A, Kubinova R, Bragina $\mathrm{O}$ et al. Socio-economic circumstances and food habits in Eastern, Central and Western European populations. Public Health Nutr 2010; 14: 678-687.

9. World Health Organization. The challenge of obesity in the WHO European region and the strategies for response. Copenhagen: World Health Organization, Regional Office for Europe, 2007.

10. World Health Organization. Closing the gap in a generation: Commission on Social Determinants of Health report. Geneva: World Health Organization, 2008.

11. Jepson RG, Harris FM, Platt S, Tannahill C. The effectiveness of interventions to change six health behaviours: a review of reviews. BMC Public Health 2010; 10: 538.

12. Jackson S. Educating children in residential and foster care. Oxford Rev Educ 1994; 20: 267-279.

13. Norwegian Ministry of Health and Care Services. National strategy to reduce social inequalities in health. Oslo: Norwegian Ministry of Health and Care Services, 2007.

14. Wollstonecraft, M. Zagovor pravic ženske. Ljubljana: Krt, 1993.

15. Suhrcke M, de Paz Nieves $C$. The impact of health and health behaviours on educational outcomes in high-income countries: a review of the evidence. Copenhagen: World Health Organization, Regional Office for Europe, 2011.

16. Lundborg $P$. The health returns to education: what can we learn from twins? Available August 15, 2012 from: http://econpapers. repec.org/paper/izaizadps/dp3399.htm

17. McDonough P, Walters V, Strohschein L. Chronic stress and the social patterning of women's health in Canada. Soc Sci Med 2002; 54: 767-782.

18. Mandemakers JJ, Monden CWS. Does education buffer the impact of disability on psychological distress? Soc Sci Med 2010; 71: 288-297.

19. Kamin $\mathrm{T}$, Berzelak N, Ule $\mathrm{M}$. The influence of education on differences in depressive symptoms between men and women in Slovenia. Zdrav Var 2012; 51: 33-42.

20. Pan SY, Cameron C, Desmeules M, Morrison H, Craig CL, Jiang $\mathrm{XH}$. Individual, social, environmental, and physical environmental correlates with physical activity among Canadians: a crosssectional study. BMC Public Health 2009; 9: 21.

21. Hillsdon M, Lawlor DA, Ebrahim S, Morris JN. Physical activity in older women: associations with area deprivation and with socioeconomic position over the life course: observations in the British Women's Heart and Health Study. J Epidemiol Comm Health 2008; 62: 344-350.

22. Scholes S, Bajekal M, Love H, Hawkins N, Raine R, O,Flaherty $\mathrm{M}$, Capewell S. Persistent socioeconomic inequalities in cardiovascular risk factors in England over 1994-2008: a timetrend analysis of repeated cross-sectional data. BMC Public Health 2012; 12: 129.

23. Cleland V, Ball K, Crawford D. Socioeconomic position and physical activity among women in Melbourne: does the use of different socioeconomic indicators matter? Soc Sci Med 2012; 74: 1578-1583.

24. Robertson A, Lobstein T, Knai C. Obesity and socio-economic groups in Europe: evidence review and implications for action. Available October 15, 2012 from: http://ec.europa.eu/health/ ph determinants/life style/nutrition/documents/ev20081028 rep_en.pdf

25. Costa G. Shift work and occupational medicine: an overview Occupat Med 2003; 53: 83-88.

26. Patel SR, Hu FB. Short sleep duration and weight gain: a systematic review. Obesity 2008; 16: 643-653.

27. World Health Organization. Diet, nutrition and the prevention of chronic diseases. Copenhagen: World Health Organization, Regional Office for Europe, 2003.

28. World Health Organization. The financial crisis and global health: report of a high-level consultation. Available October 12, 2012 from: http://www.who.int/mediacentre/events/meetings/2009_ financial_crisis_report_en_.pdf.

29. World Health Organization. Global status report on noncommunicable diseases. Geneva: World Health Organization, 2010.

30. Prättälä R, Helasoja V, Laaksonen M, Laatikainen T, Nikander P, Puska P. CINDI health monitor: proposal for practical guidelines. Available August 24, 2012 from: http://www.ktl.fi/attachments/ cindi_guidelines.pdf.

31. Hlastan-Ribič C, Djomba JK, Zaletel-Kragelj L, Maučec Zakotnik $\mathrm{J}$, Fras Z, editors. Tvegana vedenja, povezana z zdravjem in nekatera zdravstvena stanja pri odraslih prebivalcih Slovenije: rezultati raziskave Dejavniki tveganja za nenalezljive bolezni pri odraslih prebivalcih Slovenije 2008. Available August 24, 2012 from: http://cindislovenija.net/images/stories/cindi/raziskave/ CHMS2008.pdf.

32. Ohayon MM, Carskadon MA, Guilleminault C, Vitiello MV. Metaanalysis of qualitative sleep parameters $\mathrm{R}$ from childhood to old age in healthy individuals: developing normative sleep values across the human lifespan. Sleep 2004; 27: 1255-1273.

33. World Health Organization. Global recommendations on psychical activity for health. Geneva: World Health Organization, 2010.

34. Ministrstvo za zdravje Republike Slovenije. Smernice zdravega prehranjevanja delavcev $v$ delovnih organizacijah. Ljubljana: Ministrstvo za zdravje Republike Slovenije, 2008.

35. Ferligoj A. Razvrščanje $v$ skupine: teorija in uporaba $v$ družboslovju. Available March 23, 2011 from: http://vlado.fmf. uni-lj.si/vlado/podstat/mva/MZ4.pdf

36. Subhash S. Applied multivariate techniques. New York: John Wiley \& Sons, 1996.

37. Bourdieu P. Distinction: a social critique of the judgment of taste. London: Routledge, 1979.

38. Kamin T, Tivadar B. Kapital(i) in zdravje. Teorija Praksa 2011; 48: 1004-1023, 1076-1077.

39. Link BG, Phelan J, Miech R, Westin EL. The resources that matter: fundamental social causes of health disparities and the challenge of intelligence. J Health Soc Behav 2008; 49: 72-91.

40. Ross CE, Wu CL. Links between education and health. Am Soc Rev 1995; 60: 719-745.

41. Stronks K, Mheen van de DH, Looman CWN, Mackenbach JP. Behavioral and structural factors in the explanation of socioeconomic inequalities in health: an empirical analysis. Soc Health Illness 1996; 5: 653-674.

42. Ross CE, Mirowsky J. Sex differences in the effect of education on depression: resource multiplication or resource substitution? Soc Sci Med 2006; 63: 1400-1413.

43. Corsini V. Highly educated men and women likely to live longer: life expectancy by educational attainment. In: Eurostat Statistics in focus 24. Brussels: Statistical Office of the European Communities, 2010.

44. Statistični urad Republike Slovenije. Izobrazba, Slovenija. Available September 15, 2012 from: https://www.stat.si/ novica_prikazi.aspx?id=4412 
45. Rajgelj, U. Med samouresničitvijo in družbenimi pričakovanji: odnos univerzitetno izobraženih do rodnosti. Ljubljana: ZRC SAZU, 2008.

46. Kanjuo - Mrčela A, Černigoj - Sadar N. Mladim materam/ družinam prijazno zaposlovanje: študije primerov $v 7$ podjetjih v Sloveniji. Ljubljana: Fakulteta za družbene vede, 2006.

47. Stropnik, N. Položaj in problemi mladih družin z vidika zaposlovanja ter usklajevanja dela in družine. IB Revija 2006; 4.

48. Richardson, D. Child and family policies in a time of economic crisis. Child Society 2010; 24: 495-508.

49. Gauthier, A. The impact of economic crisis on family policies in EU. Brussels: EC, 2010.
50. Stropnik N. Revščina in materialna deprivacija starejšega prebivalstva: projekt $v$ okviru ciljni raziskovalni program konkurenčnost Slovenije 2006-2013. Ljubljana: Inštitut za ekonomska raziskovanja, 2010.

51. Statistični urad Republike Sloveniije. Strukturni podatki delovno aktivnega prebivalstva. Available October 8, 2012 from: http:// www.stat.si/novica_prikazi.aspx?id=4766.

52. Gabrijelčič Blenkuš $\mathrm{M}$, Koprivnikar $\mathrm{H}$, Drev $\mathrm{A}$, Vračko $\mathrm{P}$, Pirnat N, Hočevar T, Vrdelja M, Jeriček Klanšček H, Pucelj V, Kofol Bric T, Martinovič B, Kranjc I, Martinovič A. Vsevladni pristop za zdravje in blaginjo prebivalcev in zmanjševanje neenakosti v zdravju. Ljubljana: Inštitut za varovanje zdravja RS, 2012. 